\title{
What Makes Source of Scientific Information Good? Reflection on Primary and Junior High School Textbooks and their use by Teachers Presenting Particular Teaching Style through Example of Amphibians and Reptiles
}

\author{
Zofia Anna Chyleńska ${ }^{1 *}$, Eliza Rybska ${ }^{1}$ \\ ${ }^{1}$ Department of Nature Education and Conservation, Faculty of Biology, Adam Mickiewicz University in Poznan, POLAND
}

Received 1 March 2019 - Revised 13 April 2019 - Accepted 15 April 2019

\begin{abstract}
Textbooks are one of the most important teaching aids in education. They often serve as the main or the only source of information for students and teachers. The aim of this study was to analyze the sources of students' scientific knowledge -teachers and textbooks, with focus on information about amphibians and reptiles. Authors have conducted an analysis of the content of twelve nature and biology textbooks, with the focus on: a core biological idea, the presence of surveys and summaries, appealing graphics and factual errors. The teachers participated in in-depth interviews, and were analyzed for the reflective insight considering e.g. presence of substantial mistakes or shaping students' attitudes. Authors proposed new framework for describing teaching styles based on the dominant characteristics of their teaching process, the teachers were classified as - Didactical, Pedagogical or Ethical teacher. None of the analyzed books were flawless. The most common errors concerned the movement apparatus and the taxonomy. Authors have found out statistically significant correlation between teachers with wider knowledge, and their declaration of more diverse and suitable methods during the lessons. Teachers who do not declare such activities were more probable to put less focus on shaping students attitudes and to make more errors.
\end{abstract}

Keywords: biology education, herpetology, sources of scientific information, textbook analysis, teacher beliefs

\section{INTRODUCTION}

According to Bertrand Russell we might construct our knowledge by acquaintance and by description. Knowledge by acquaintance is constructed through a direct (experience-based) interaction between a person and the object. Knowledge build by description involves the use or application of concepts (Russell, 1912). Implementing these into school environment would mean that a teacher should create possibilities for students to construct their own knowledge in both ways. It also indicates that teachers themselves while presenting new information to students can be perceived as source of scientific information (Bybee, 1989; Kandzia, 2018; Szyling, 2011). As such we might perceive textbooks as well (Brzezińska, 2008; Kandzia, 2018; Szyling, 2011). Students' sources of scientific information have been constantly changing over the years. At the beginning of the 20th century, these sources were teachers and textbooks. Today, in the 21st century, the Internet is becoming a new and important source (Erdoğan, Coşkun, \& Uşak, 2011). At the same time, the way teachers and students works in many schools still relays on these two major sources of information which are teachers and textbooks. The research conducted in primary and secondary school of the city of Poznan (Basińska, Pietrala, Cole, \& Dziubalska-Kołaczyk, 2012) shows that science lessons mainly consist of reading information in a textbook and copying notes from the board. Additionally, it is known from literature that both textbooks and teachers are prone to alternative conceptions (Cardak, 2009; Gericke,

(C) 2019 by the authors; licensee Modestum Ltd., UK. This article is an open access article distributed under the terms and conditions of the Creative Commons Attribution License (http://creativecommons.org/licenses/by/4.0/). \zofias@amu.edu.pl (*Correspondence) $\$ elizaryb@gmail.com 


\section{Contribution of this paper to the literature}

- None of the investigated students' sources of scientific knowledge were free of errors. Teachers use limited sources of students' scientific knowledge in addition to themselves and textbooks.

- Results showed that there is a strong correlation between a teacher's claims that respect toward organisms is significant and claims about the importance of a direct experience with nature. At the same time, teachers did not stress the value of shaping attitudes during lessons.

- Authors proposed new framework for describing teachers teaching styles based on the dominant characteristics of their teaching process. The teachers' styles were classified as - Didactical, Pedagogical or Ethical.

2009; Yates \& Marek, 2014). For that reasons we have decided to conduct research aiming to compare both sources of students' scientific information.

\section{Problems with Analysed Sources of Scientific Information}

It might be assumed that sources of scientific information should be free from mistakes. However, as we have mentioned above, both analyzed sources of information might possess misleading information, mistakes, and misconceptions. One of the sources of probable mistakes in textbooks is presented by Bizzo and Caravita (2012) the idea of a "saber tooth tiger tale". It is the kind of mistake that occurs when information from textbooks is not actualized or is rewritten without verification. Bizzo and Caravita (2012) claim that this kind of errors might not only have clearly academic consequences but also more importantly life-saving outcomes. An example of this was found that in one of the Brazilian textbooks where first aid information about the proper treatment of the bite of the venomous snake was rewritten from the textbook from United States. The problem was that in the US textbook, it was presented for a different species of the snake. This kind of treatment-proposed by the US textbookconducted after a bite of the Brazilian snake species might actually do more harm than good. The other and most common source of mistakes is a consequence of a phenomenon that can be named as educational reductionism. By explaining phenomena in a simplified manner, teachers tend to reduce excess information (Barrass, 2010; Yip, 1998). For example as Yip (1998) presents teachers who sometimes oversimplify mechanism of photosynthesis stating that this process "is made up of light reaction and dark reaction" (Yip, 1998) what as research shows leads to students misunderstandings of the process such as - students thinking that light dependent phase and light independent phase are conducted one after another (not simultaneously) and also that light dependent phase is conducted during the day and light independent phase during the night (Yip, 1998). This could be avoided either by providing students with more detailed description of the process or by using scientifically correct terms "light dependent phase" and "light independent phase" (Yip, 1998).

Some mistakes might be caused by misunderstandings in general communication. Communication itself can be verbal and nonverbal, through the use of many channels, such as visual, auditory, tactile (like in Braille), and other. Usually, in school communication, two channels are dominant: verbal and pictorial (Fay, Garrod, Lee, \& Oberlander, 2003). Communication, as a process, is quite complex, and a number of misunderstandings can happen even if the relation between sender and receiver is clear, and the sender explains own ideas transparently and the receiver is listening actively, but at the same time both of them interpret information according to their experiences, concepts, and pre-existing knowledge (Rubenstein, 2000).

\section{Theoretical Framework}

The main sources of scientific information in the classroom are textbooks and teachers. Those two elements are fundaments of the communication of such information in the classroom - the textbook provides mainly content and might have some cognitively challenging tasks and the teacher is the director of the communication in the classroom, who designs those communications and motivates students to be a part of this didactic process.

Successful education requires successful communication. This is also true for science education. If a science community wants society to understand their work, they have to communicate in a proper and adequate manner for their target age group, and with the usage of appropriate tools. Among the tools for scientific communication, humans have created textbooks. Lemke (1988) said that textbooks are semiotics hybrids, as they use specific written verbal language (in the meaning of communication) as well as pictorial elements. From this point of view, textbooks participate in symbolic interactions as important elements of human culture (Izquierdo, Marquez, \& Gouvea, 2008). As such cultural products, textbooks are the expression of their authors' enunciations; they are created in a specific social context, in agreement with the core curriculum that is obligatory at that moment, etc., and in this case, the role of the textbook in communication is important. As Wendland mentioned (2011), communication cannot be reduced to transferring information, but this activity is an important element of interaction. Jakobsen also noticed 
that communication has different functions, for example: informational, emotional, cognitive or poetical (Jakobson, 1987). That indicates that a good transfer of information requires communication. This should apply to both analyzed sources of scientific information - textbooks and teachers.

\section{Textbooks}

The authors of textbooks adjust them to the role of the textbook in education, which has been changing through time. The basic role of the textbook is informational, which should help students and teachers in the didactical process. Textbooks serve as the synopsis for the lessons and the guide to every activity and exercise in the classroom at the same time (Edling, 2006). Okon (2003) distinguished four major roles of textbooks in education -informative (mentioned earlier), transformative, self-educational, and motivational. However, Izquierdo and coworkers (2008) showed that textbooks should undertake a new role where students may attend to more cognitively challenging tasks. In their research about chemistry textbooks, they claim that textbooks should primarily generate cognitive conflict, which will encourage students to seek further exploration and become scientists by themselves (Izquierdo et al., 2008). Also as it is presented in work of Lau and coworkers (2018) the role of the textbook is different in traditional classroom setting in comparison to e-learning environment (Lau et al. 2018). And even though the role of the textbooks might has change and decentralize through the time (Vera, 2018) it is important to evaluate textbook role in nowadays education.

Researchers are still investigating textbooks (Calado, Scharfenberg, \& Bogner, 2015). Fuchs and Henne (2018) claim that those research are conducted superficially and rarely reach common conclusions (Fuchs \& Henne, 2018). Nevertheless, Abimbola and Baba (1996) notice that every evaluation and research on textbooks is mainly focused on four areas: (a) The development and validation of textbook selection criteria and their utilization in evaluating textbooks, (b) the evaluation of specific content areas of science/biology across science/biology textbooks, (c) readability studies, and (d) studies focused on misconceptions in textbooks. In this study, the authors focused on two of these - the evaluation of the specific content areas, and misconceptions in textbooks. The first part was done by investigating the core idea behind the chosen topic presented in the studied textbooks. The core idea is understood as an element or theme which will help students to understand and construct knowledge about a new topic (National Research Council, 2012). Those core ideas can be observed as usually presented in textbooks in the form of any keynotes or guidance to help students to understand each chapter. The second part was done through analysis of the content of textbooks and is described in detail in the Methods section. Previously, content analysis was used to investigate biology textbooks in such areas as genetics (Gericke, 2009), taxonomy (Trowbridge \& Mintzes, 1988), human biology (de Irala, Urdiain, \& López Del Burgo, 2008), ecology (Roth, Bowen, \& McGinn, 1999), and zoology (Yen, Yao, \& Chiu, 2004). In each of the mentioned areas, mistakes and misleading information were revealed, independently of the country or education phase for which the textbook was designed. The aspect which was not explored or compared until now is the problem of students' confusion while differentiating between separate animal divisions. This is one of the reasons we took amphibians and reptiles as commonly confused clusters of animals (Yen et al., 2004). Furthermore, the amphibians and reptiles are the most endangered groups of vertebra (Gibbons et al. 2000; Gardner, Barlow \& Peres 2007), especially those living in South America where decreasing number of species is one of the highest and the fastest reported decline of biodiversity in the world (Lips et al. 2005; Böhm et al. 2013). The other reasons amphibians and reptiles were chosen as an example to this research is that they are crucial from an environmental protection point of view and for ecological reasons (Vitt \& Caldwell, 2013). For that reason, attitudes toward those groups are often the focus of many other researchers (Prokop \& Tunnicliffe, 2008; Tomažič \& Šorgo, 2017).

\section{Teachers}

The teacher is another source of students' scientific knowledge. It is believed that they should also possess excellent communicative skills. Furthermore, teacher communication in the context of textbooks should happen at multiple levels (Dufresne, Gerace, Leonard, Mestre, \& Wenk, 1996; Pea, 1994). First of all, teachers should evaluate textbook content by themselves and based on that evaluation, they should work with students and provide new information, which appears in other scientific sources. Moreover, teachers should work with the authors of textbooks, to evaluate their work and present suggestions, errors, or misunderstandings which they have noticed (Barron \& Darling-Hammond, 2008; Slavin, 2008). Theoretical and ideal relations of communication between teachers, students, textbook authors, and other sources of scientific information are presented in Figure 1. A good source of information requires interaction with the recipient, and this interaction is communication, which can inspire, for example, students to give their feedback about the source of scientific information. In an ideal situation, students might give this feedback, improve, for example, textbooks and present what, in their opinion, should be applied from other sources of information to improve textbooks for the users by users. But from our current knowledge and pilot studies, it is known that students have small influence on the scientific community (Chyleńska \& Rybska, personal communication, 2018; Mackay, 1971). Additionally, a good transmission of information 


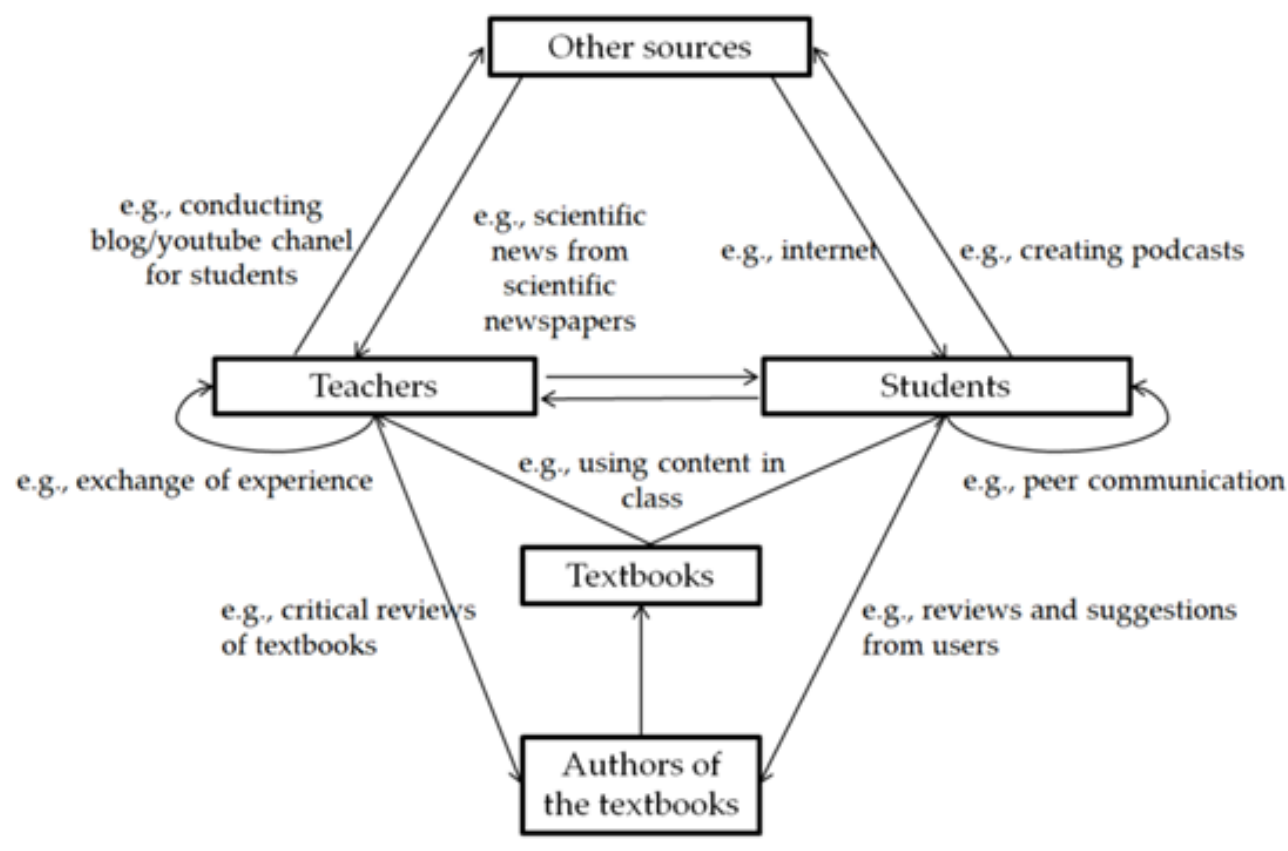

Figure 1. Ideal framework of communication between students, teachers, textbooks, authors of textbooks, and other sources of scientific information for teachers

requires a constant exchange of information between all of the participants. It indicates that it is not only teachers who should communicate with students and vice versa. In this process, the authors of textbooks should also be involved and communicate with both teachers and students. It also involves the exchange of experience and information between teachers and between students. Such networks of communication could be evaluated in the future as a possibly good example of communication and transmission of information.

The pilot study was conducted by the authors, involving editors and teacher advisors. Simultaneously, through interviews with teachers and from emails exchanged with publishing houses, the authors drew the conclusion that there is insufficient communication between editors, teachers, and students. The gained data were limited, so they only qualified as a mention in the article. This pilot study showed that evaluation and cooperation between teachers and editors is needed and might lead to handing down the feedback information to authors of the textbooks, which is currently very rare, at least in Poland (Chyleńska \& Rybska, personal communication, 2018).

There are three basic sources of students' information-textbooks, teachers, and other (out of classroom) sources - and in the following part, we have focused on the analysis of school sources of scientific information and when and how they can be used by a teacher.

In the following paper, the authors present only part of the sources introduced in Figure 1. Research on other sources and interaction between them would require a separate study.

\section{Proposed Category of Teaching Styles}

Research carried on teaching and learning styles has shown the uniqueness of different styles of both activities and identified the characteristics associated with each style. Some researched would suggest that teaching style should match learning style of students (eg. Miller, 2001; Stitt-Gohdes, 2001). Although there are benefits to the matching those two styles in education, thus on the other hand it appears that doing that does not guarantee better results (Brown, 2003; Felder \& Brent, 2005). Additionally Felder and Brent (2005) suggested that the optimal teaching style should be a balanced one that a teaching style time to time matches students' preferences, and sometimes goes against their preferences. Such strategy is supposed to force students to develop intellectual and critical skills. When considering Grow's Stages of Self-Directed Learning Model a reader might notice that all described by Grow (1991) teaching styles are hierarchical from Authority, coach, trough Motivator, guide, Facilitator up to Consultant, delegator presents Decreasing levels of control of learning. In our research we wanted to diagnose what is the most important for teachers in their teaching style, how do teachers perceive the possibility of placing the student in the center of educational process, what aspect of teaching is the most important as an outcome - 
would it be content knowledge, attitudes or higher skills like critical thinking? In this approach, we were similar to idea presented by Liu, Qiao and Liu (2006). These researchers in order to asses teaching style among university teachers have used several factors including learner-centered activities, personalizing instruction, relating to experience, assessing student needs, climate building, participation in the learning process, and flexibility for personal development. It would allow them to check whether a teaching style is teacher oriented or student oriented, but we were trying to take a slightly different perspective, that could allow us to answer questions raised by us. Taking more general perspective it can be assumed that teachers can focus on one of the three aspects in their work-philosophical (Schulman \& Mekler, 1986), pedagogical (van Dijk \& Kattmann, 2007), and didactical (Friedrichsen et al., 2009). Based on this division, the authors of this publication created three major categories of teaching style: ET - ethical teacher (with humanistic approach as dominant in teaching style, as described by Seel and co-workers, (2011), PT - pedagogical teacher, DT - didactical teacher (mostly focused on content knowledge). Depending on the answers from the interviews, teachers were assigned to each category. Specific information about the interviews is mentioned in the Methods. For example, if a teacher avoids shaping students' attitudes or tries to transfer this responsibility to other people (e.g., students' parents or other students), and his or her goal is only to convey knowledge, we can presume that this teacher can teach mostly on a didactical level-and therefore, they are assigned as didactical teachers (DT). There are also teachers who, in their teaching style, put more focus on values, attitudes, and principles. Teachers of this kind were classified as ethical teachers (ET). The last, intermediate teaching style observed by us among teachers was found in pedagogical teachers (PT) - this kind of teacher is focused on students' knowledge and skills, and is consciously using a variety of teaching methods, and is aware of their own role in the teaching process. However, despite that, this kind of teacher chooses not to shape students' attitudes. In the light of this newly introduced division, using only Pedagogical Content Knowledge as a tool for a teacher's understanding of a particular subject matter but not shaping attitudes is not enough (Zembylas, 2007).

Each of the teaching styles has its weaknesses-e.g., a didactical teacher might convey the content at a high level, but it is likely that he or she will lose the ethical part during the lesson, with less chance of affecting students' attitudes. The balance between the appropriate didactic, pedagogical, and ethical style of teaching is delicate. Especially, it is important to maintain a balance, as it is through the teacher's perspective that a student perceives the teacher, and the results of this perception are projected on the teacher's communication with the student.

Despite the style of teaching, one of the most important skills a teacher should have is the ability to reflect on their own work. Reflection makes teachers aware of their flaws and opportunities, which they can use in didactical process (Brookfield, 1995). That way, a teacher can reflect on their own actions and evaluate their effectiveness. Metacognition, which emerges from critical thinking, is reflected in three possible dominant teaching styles: Didactical, pedagogical, and ethical - especially in the face of new challenges and innovations developed in science (Jefferies, Carsten-Stahl, \& McRobb, 2007; Saunders \& Rennie, 2013).

One of the main purposes of science education is to educate a scientifically literate society. People in society possess a variety of conceptions, also about animals, which are significantly different from scientific knowledge. It has been shown that even though teachers are important sources of scientific information for students, they are not infallible, in relation to their knowledge about birds (Cardak, 2009; Kubiatko, Usak, \& Pecusova, 2011), insects (Barrow, 2002), amphibians, and reptiles (Braund, 1991; Yen et al., 2004). It has also been shown that teachers use textbooks as a main source of knowledge (Edling, 2006). The authors did not investigate mutual relations between teachers and textbooks nor how mistakes which appear in textbooks can influence the conceptions that teachers have. The teachers' ability to reflect on their own as well as external knowledge, and on the epistemological perspective in the scientific sources of students' information plays an important role. In the analysis of teachers as the source of students' scientific knowledge, the authors focused on the categories of teaching styles as given below. To analyze teaching styles, the theory of pedagogical content knowledge is often used; however, since this theory does not focus on the important element of communication in the classroom between the student and the teacher, a broader approach than PCK was applied (Magnusson, Krajcik, \& Borko, 1999). The approach proposed above gives an opportunity to show the difference between what quality of communication we have in the classroom at the moment and what higher-quality standards we are able to achieve by analyzing teaching styles of the teachers.

\section{The Aim and Research Questions}

The aim of the presented research is to diagnose the problems and gaps in communication processes that occur between all elements involved in educational discourse. The authors want to propose a framework for desirable pathways of communication of scientific knowledge that is presented in Figure 1, which involves teachers, students, textbooks (and their authors), and other sources of scientific information. On this basis, we would like to show not only gaps (in the meaning of processes that are hardly ever present in real school situations) but also to analyze the ways this discourse on the topic of amphibians and reptiles looks like. In order to analyze it, we have set the following research subjects: 
1. Textbooks content analysis with a focus on analysis of conceptions about amphibians and reptiles;

2. Teachers' ideas and beliefs about amphibian and reptile analysis on the basis of in-depth interviews.

To fulfill those tasks authors asked the following research questions:

1. How does the source of scientific knowledge as a textbook functions?

To answer this question Authors focused on such aspects of textbooks as: core ideas in textbooks, graphic representation of a typical amphibian and reptile, presence of cognitively interesting tasks and handout/aids, presence of the errors which might lead to the formation of students' alternative conceptions.

2. What is role of the teacher as a source of scientific knowledge?

To answer this question Authors focused on such aspects of teachers like: role of their personal knowledge in diagnosing students' alternative conceptions about amphibians and reptiles, their reflectiveness towards both it and the used textbooks (and finding possible errors in them), their teaching style (Didactical, Ethical or Pedagogical) and their focus on constructing knowledge, skills or shaping attitudes. Additionally also the use of practical or theoretical approaches during the didactic process.

\section{MATERIALS AND METHODS}

The education system in Poland is currently undergoing reform. Until 2017, it was divided into primary school (6 years, students aged between 7-14 years old), junior high school (3 years, 14-16 years old) and high school (3 years, 16-19 years old). Since 2017, it has been divided only into two schools (primary school - 8 years, 7-14 years old - and high school-4 years, 14-18 years old). Textbooks for primary schools were designed for a plan 1 hour per week of nature curriculum, and textbooks for junior high school are also designed for plan 1 hour per week of biology. Before the reform, students had to participate in 3 exams, at the end of each education level-each of the exams was a pass to the next education level. Since the reform, they have two exams - at the end of primary school and at the end of high school. The exam in the end of high school is the same as the admission exam to the chosen direction at university.

\section{Textbooks}

In the first stage, authors chose samples from textbooks commonly used in Polish schools and analyzed them in the context of their herpetological content. The obtained data from the text in the textbooks were categorized and subjected to quantitative analysis (Silverman, 2013). Content analysis was used to analyze the textbooks as, based on Reference (Babbie \& Benaquisto, 2009), this type of analysis can be treated as unreactive research -in the sense that during this analysis, there is no direct experiment or influence on the environment. When analyzing the content, textbooks were individually assessed for the information concerning the clusters of amphibians and reptiles according to chosen criteria, described below. All textbooks and content gathered from them were consistent with the curriculum and mandatory for the student.

The key issues that the analysis of the content focused on were:

1. The presence of the core ideas (Costa, Howitt, Anderson, Hamilton, \& Wright, 2008);

2. A versatility/diversity of posted images (Postigo \& López-Manjón, 2018);

3. Cognitively interesting tasks (Ghaderi, 2010; Lumpe \& Scharmann, 1991);

4. Summaries of the systematics (Lee, 2010);

5. The presence of the factual errors (Abimbola \& Baba, 1996).

Regarding the presence of the core idea in a chapter, the authors expected that textbooks might present amphibians as pioneers in some respect-as the first animals which came out on the land and are consequently semi-land semi-water organisms - or focus on their unique evolutionary solutions, like their expanded circulatory system with gas exchange through the skin. In fact, reptiles should be presented as the first truly land vertebrate organisms with their adaptation to reproduction independent from water, excellent water management, and more versatile movement apparatus (in comparisons with amphibians). As a core idea might be accepted any other scientifically correct leading thought or idea which would help students to interpret the data, for example, from the perspective of the role of amphibians and reptiles in protecting the environment or adaptation to this environment.

While analyzing images, the authors investigated what the photos were showing regarding the diversity of clusters of amphibians and reptiles, including variation in representing the subclasses. In addition, some attention was directed at the origin of the particular animal presented in the illustrations (whether the pupils can encounter those particular species in their direct surrounding-native or exotic).

As for transparency, the summaries in the textbooks were analyzed by looking for the presence of various forms of presentation (such as texts, graphs, and tables). Additionally, in that part, authors investigated if cognitively 
stimulating tasks appear in the summaries, which would help students to systematize their knowledge and construct new links between previously known concepts and those which they discovered in the new chapter.

Substantial errors were one of the most often found problems/shortcomings in the analyzed textbooks. Due to the variety of errors found in textbooks, we distinguished four categories: Linguistic, logical, classification, and substantial mistakes. The last one was divided into six subcategories related to the morphology, physiology, ecology, and locomotive skills of the analyzed groups. In addition, we separated linguistic errors which appear when a used word or phrases might lead to misconceptions or is wrong (misspelled) and errors in the herpetological systematics, for example, a wrong description of a species.

Altogether, 12 textbooks were used for the analysis. Out of those, 4 were dedicated to primary school pupils (K4-6) and 8 to junior high school students (K10-12). All textbooks were in line with the curriculum. Detailed information, including titles, publishing houses, and the year of release, educational stages, and classes, is included in Appendix.

\section{Interviews with Teacher}

Analyses of teachers' conceptions as a source of scientific knowledge were conducted through in-depth interviews. The same researcher (A1) carried out the interviews. The fieldwork was conducted in separate rooms in the teachers' schools or directly in their classrooms, after getting the consent of the interviewee. Ten teachers were interviewed ( 5 from primary school and 5 from junior high school), 9 of who were female and 1 was male. Authors established instructions for the interview based on Reference (Gatt, Tunnicliffe, Borg, \& Lautier, 2007). The instructions with the questions were consulted with another researcher (A2). Every question was reviewed and (if there was a need) improved before conducting the interview.

The teachers' answers were recorded on an audio recorder. Each teacher had as much time as they needed to answer the questions. Teachers' interviews were foretold, and conducted with them knowing the topic but not specific questions. Questions did not consider directly their knowledge about amphibians and reptiles, but their information was verified indirectly to avoid unnecessary stress or considering this interview as a test. That way, the teachers were focusing on their experiences at work with students. First, three questions were asked to assess the type of the teachers - on which part of teaching they most focus on (knowledge, skills or attitudes) and at the same time to determine if they would favor or neglect zoology. Next, three questions considered teachers' observation and experiences gained during teaching about amphibians and reptiles. A full list of questions is available in Appendix.

To be classified as an ethical teacher, a person should in their answers refer to shaping attitudes, hands-on activities, social abilities, and teamwork, with special emphasis on respect to living organisms, etc. As an ethical category was qualified any category which referred to experience, shaping attitudes, pro-environmental interaction with society, and teachers seeing themselves as a person who can influence pro-environmental attitudes of students and consider it as the priority. A full list of qualified categories is presented in the Appendix.

\section{Analysis of the Interviews and Coding}

The interview analysis method was based on Creswell and Miller (2000). To extract teachers' concepts, answers were analyzed with the use of content analysis, then qualitative data were coded to quantitative data. To ensure inter-rater reliability, an independent researcher (A2) revised the created code system itself and the assignment of teacher statements to appropriate elements/codes/categories. In disputable cases, differences were discussed until researchers reached an agreement. The authors undertook inductive approach-developed the categories on the basis of students' answers. The initial coding agreement rate was $95 \%$ and any disagreements were settled by discussion.

In the transcripts, the researchers looked for direct and indirect indicators of some statement. For example, teachers could, in question 1, directly say that "knowledge is important to me" or indirectly show they prefer "information which students have and gain from the lesson is the most important element of didactic process for me."

Coding of the data was conducted in sequence. At first, the researcher did a quick superficial revision of the interviews to have an overview of the data, and then created in vivo codes (Creswell \& Miller, 2000) on the basis of actual expressions in data. The next step was the consolidation of the codes-similar codes were grouped, and redundant codes were removed.

Codes were aggregated to themes, which resulted from questions asked in the interviews. Detailed information about creating codes and examples of the answers to each code are included in Appendix. 


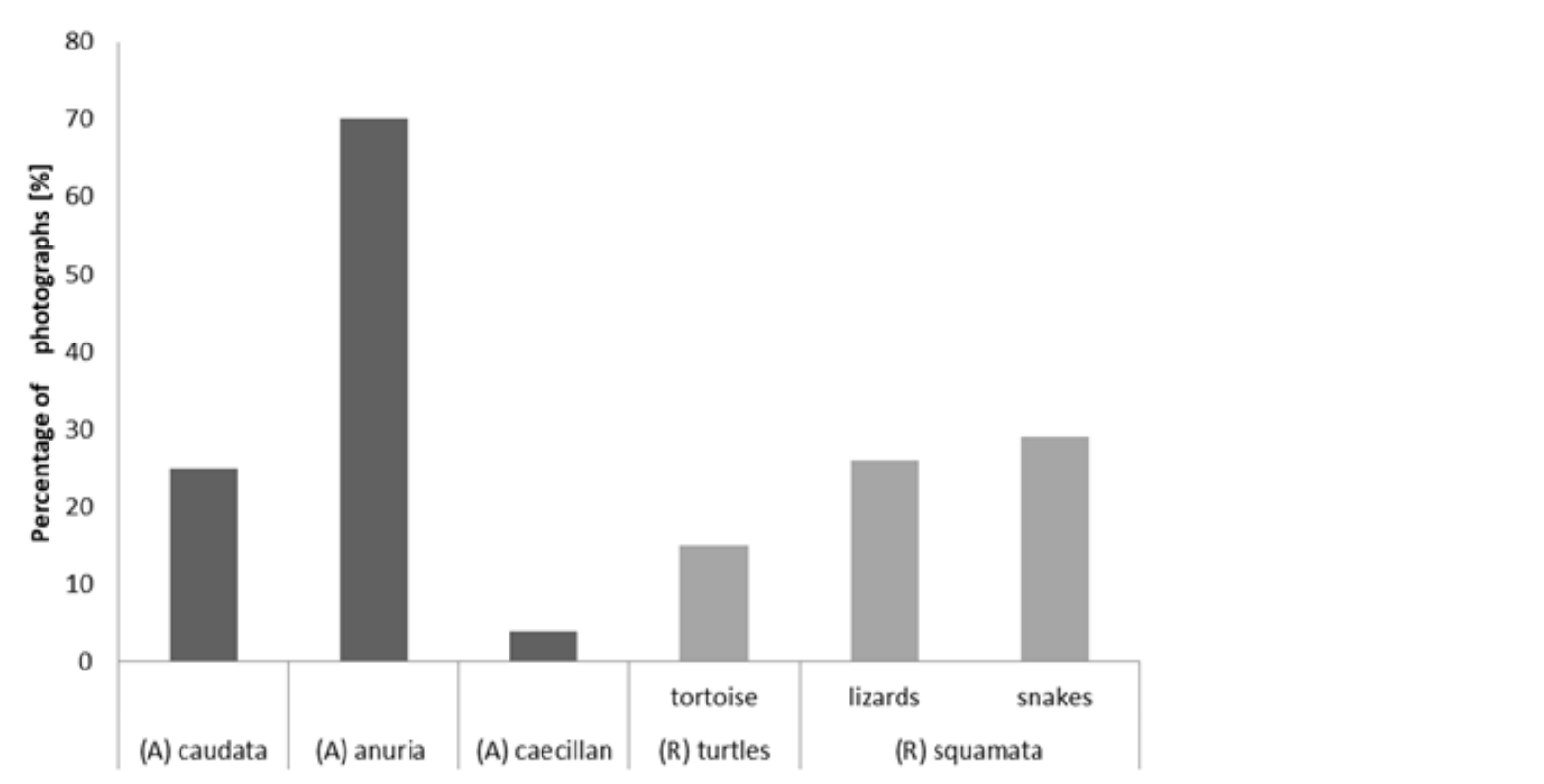

Figure 2. The diversity of photographs presented in analyzed textbooks. Orders of amphibians (A): Caudate, anuria, caecilian. Orders of reptiles $(\mathbf{R})$ : Turtles and squamata

\section{Statistical Analysis}

The data were input to Excel. At first, data were measured in terms of frequency in each category; then, data were input into the program Statistica ${ }^{\circledR}$ and basic statistics (average standard, deviation) and Spearman correlation were measured (Trigwell, Prosser, \& Waterhouse, 1999). A matrix of correlation was made from the quantified questionnaires' in Excel (2013, Microsoft). The statistical significance of the correlation used for the results was 0.05 with the following addition of the Bonuferroni correction. Statistic results with a significance lower then $p=0.05$ were not included in the analysis.

\section{RESULTS}

\section{The Textbook Analysis}

\section{Core ideas in the textbooks}

None of the studied textbooks were free of errors in all 4 key areas of interest-textbooks with good and representative pictures had substantive mistakes, and those with the most correct information contained underdeveloped graphic sections.

Additionally, none of the textbooks had a core idea-information or questions which might help students to understand the differences and uniqueness of the investigated taxa. In 5 out of 12, some general ideas appeared, mainly concerning adaptations to the environment, but in none of the textbooks were amphibians presented as pioneers in a new land environment and the reptiles as independent conquerors of the land environment which can reproduce without water (due to fetal membranes) etc. One of the textbooks presented poikilothermy (coldbloodedness) as a core idea for these groups of animals and connected it with an undeveloped circulatory system.

\section{Variety of posted images}

Images were not diverse; although it might also represent that the number of species in this order is not equal. For example, caecilians are a minority of alee amphibian species, so their representation might be rarer, as they are rarer in nature. As a typical amphibian, a frog was usually presented. Various species from the order anuria were the most represented (71\%), then caudate (25\%), and caecilian (4\%) (Figure 2 ).

In the case of reptiles, representatives of the squamata order were presented as a typical reptile (lizards $-25 \%$ and snakes $-41 \%)$ and were more frequent in textbooks than representatives of the tortoise (13\%). The variation of presented photographs in all the textbooks is presented in the Figure 2. 


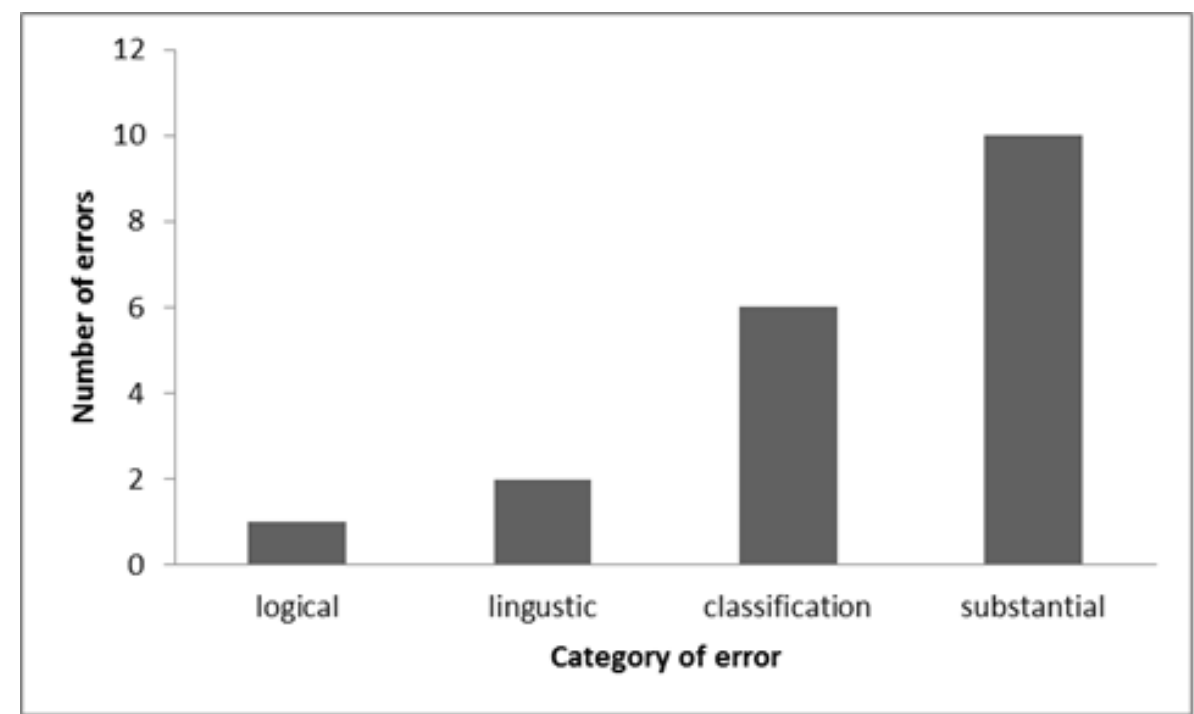

Figure 3. Summary of errors found in all textbooks assigned to categories-logical, linguistic, classification, and substantial

\section{Summaries of Presence of Systematic and Cognitively Interesting Tasks}

None of the analyzed textbooks contained tasks which might be cognitively interesting or/and which might support transformation of information in students' minds. In some cases, sets of exercises were provided, but they mainly summarized gained knowledge or were only reconstructive, and they were neither cognitively stimulating nor were they designed with the aim of shaping students' attitudes in mind.

Furthermore, we had assumed that well-designed summaries should show the diversity of analyzed groups, and as there are not many species of amphibians and reptiles in Poland, native species would all be mentioned or presented in the photographs. However, only 3 out of 12 analyzed textbooks presented sufficient summaries allowing for comparisons between taxa.

\section{Substantial mistakes}

The errors/defects in the textbooks can be assigned to one of the categories in which the mistake occurred: Logical, linguistic, classification and the substantial errors that can be further divided into: Ecological, behavioral, physiological, morphological, anatomical, and taxonomical. A summary of all the mistakes found in all the textbooks is shown in Figure 3.

Examples of the errors and misleading information about amphibians and reptiles are presented in Table $\mathbf{1 .}$ There were fewer errors about reptiles than amphibians in the analyzed textbooks, although they still represented two categories: Linguistic and substantial (anatomical and taxonomical subcategories). 
Table 1. Errors and misleading information regarding amphibians and reptiles found in textbooks

\begin{tabular}{|c|c|c|}
\hline $\begin{array}{l}\text { Category of } \\
\text { error }\end{array}$ & Example of error & Explanation of the error and the corrected answer \\
\hline \multicolumn{3}{|l|}{ AMPHIBIANS } \\
\hline $\begin{array}{l}\text { Substantial - } \\
\text { physiological }\end{array}$ & $\begin{array}{l}\text { State of numbness which is equal to } \\
\text { hibernation }\end{array}$ & $\begin{array}{l}\text { Not all of the states of numbness are hibernation; for example, } \\
\text { estivation and torpor are also present. }\end{array}$ \\
\hline $\begin{array}{l}\text { Substantial - } \\
\text { morphological } \\
\text { and behavioral }\end{array}$ & $\begin{array}{l}\text { Thanks to pores in the skin, amphibians } \\
\text { don't have to drink water }\end{array}$ & Despite of the thin skin, amphibians still drink water \\
\hline Logical & $\begin{array}{l}\text { The color of amphibians depends on } \\
\text { their environment of living }\end{array}$ & $\begin{array}{l}\text { The color of the animal depends on their pigment cells. They can } \\
\text { adjust the color to environment but not without pigment cells. }\end{array}$ \\
\hline Linguistic & Animals of land and water & Should be: Animals of water and land \\
\hline $\begin{array}{l}\text { Substantial } \\
\text { ecological }\end{array}$ & $\begin{array}{l}\text { Amphibians are observed in every } \\
\text { continent }\end{array}$ & They are not observed in Antarctica \\
\hline $\begin{array}{l}\text { Substantial - } \\
\text { taxonomical }\end{array}$ & Photograph signed as tree frog & It is not a tree frog (Hyla arborea) \\
\hline Linguistic & $\begin{array}{l}\text { Sufficiently moist (caecilian), like an } \\
\text { earthworm digging corridors in the } \\
\text { ground }\end{array}$ & $\begin{array}{l}\text { This comparison may lead to the idea that caecilian is an } \\
\text { earthworm-it would be good to highlight the difference or specify } \\
\text { that it is an amphibian }\end{array}$ \\
\hline Logical & $\begin{array}{l}\text { Tailed amphibians (Caudata) drag their } \\
\text { abdomen on the ground because their } \\
\text { legs are weak }\end{array}$ & $\begin{array}{l}\text { Tailed amphibians drag their abdomen on the ground not because } \\
\text { their legs are weak but because of the construction of their } \\
\text { shoulder and hip rim }\end{array}$ \\
\hline $\begin{array}{l}\text { Substantial - } \\
\text { taxonomical }\end{array}$ & $\begin{array}{l}\text { Hyla arborea sometimes is called tree } \\
\text { frog }\end{array}$ & $\begin{array}{l}\text { In Polish, Hyla arborea is called "rzekotka". The name of the tree } \\
\text { frog "żaba drzewna" suggests that it belongs to the Ranidae, not } \\
\text { the Hylideae family }\end{array}$ \\
\hline $\begin{array}{l}\text { Substantial } \\
\text { ecological }\end{array}$ & $\begin{array}{l}\text { "a lot of amphibians spend their life in } \\
\text { woods and gardens" }\end{array}$ & $\begin{array}{l}\text { That suggests that woods and gardens are important habitat for } \\
\text { amphibians-it should be highlighted that access to a clean water } \\
\text { reservoir and moist environment is crucial for them in addition to } \\
\text { choosing woods or gardens. }\end{array}$ \\
\hline Classification & $\begin{array}{l}\text { Amphibians are divided to orders Anura } \\
\text { and Caudata. }\end{array}$ & There is also a third taxon, Caecilians. \\
\hline $\begin{array}{l}\text { Substantial - } \\
\text { taxonomical }\end{array}$ & $\begin{array}{l}\text { On the photograph-amphibian } \\
\text { described as yellow-bellied toad }\end{array}$ & $\begin{array}{l}\text { The photograph shows Bombina orientalis-oriental fire-bellied } \\
\text { toad }\end{array}$ \\
\hline \multicolumn{3}{|l|}{ REPTILES } \\
\hline $\begin{array}{l}\text { Substantial } \\
\text { anatomical }\end{array}$ & $\begin{array}{l}\text { Scheme of the reptilian egg is described } \\
\text { without fetal membranes }\end{array}$ & $\begin{array}{l}\text { Fetal membranes are one of the crucial evolutionary advances of } \\
\text { reptiles, which made it possible to make their reproduction } \\
\text { independent from water }\end{array}$ \\
\hline Linguistic & $\begin{array}{l}\text { Foreign species of reptiles have only } \\
\text { order names and a sand lizard has a full } \\
\text { species name }\end{array}$ & $\begin{array}{l}\text { All species should be presented in one version-full name or just } \\
\text { order. }\end{array}$ \\
\hline $\begin{array}{l}\text { Substantial - } \\
\text { taxonomical }\end{array}$ & The green lizard as a Polish reptile & $\begin{array}{l}\text { The green lizard is not a Polish reptile; Slovakia and the Czech } \\
\text { Republic are the northernmost countries where this species is } \\
\text { present. The only account of its encounter in Poland is } 40 \text { years old. }\end{array}$ \\
\hline
\end{tabular}

\section{Teachers' interviews}

Teachers' interviews revealed a variety of approaches toward teaching about amphibians and reptiles. Differences are apparent even in the statements about the amount of time they are willing to spend in order to provide sufficient information about those two groups. Additionally, only some of them (four out of ten) were aware of dire need to work on students' attitudes toward animals, with the use of the activities which they should be introducing in the classrooms. The other group (five out of ten) considered the herpetological content only as an obligatory element of knowledge presented in curriculum. Based on those answers/whole interviews, teachers were assigned to categories. Only one teacher was assigned as ET, three were assigned as PT, and six as DT. All of the junior high school teachers and one from primary school presented the DT teaching style. The teachers were assigned as didactical teachers (DT) based on responses to the first question, such as:

"The knowledge is the most important of course, as it is checked during the exams (...)". "Shaping the attitudes require too much time, students should shape their attitudes on their own". 
Teachers assigned by us to the pedagogical teacher (PT) group said:

"In my work, the knowledge and skills are the most important-I want to be sure that when they eventually leave the school, they are able to resolve different problems and know why and how their resolutions worked. Human health care is a good example - after my lessons I hope they will understand the cause of bacterial infections and know when it is necessary to use antibiotics."

Teachers assigned by us to the ethical teacher (ET) group, which includes in it other two kinds of teaching styles, said:

"I think we can't dismiss knowledge and skills, because they are important, although I think that shaping attitudes are the most crucial thing. And I tell you why - only if my kids will have an emotional connection with something, they will care about it and try to protect it. The rabbits children are helping to rise, are a good example or their own pets - the children are emotionally connected to these animals, so they are inclined to protect them."

\section{Correlation between Teachers' Ideas}

The goal of the interviews was to investigate the experiences of the teachers with teaching and to investigate how they (in) directly shape students' pro-environmental attitudes. The results below present a correlation between opinions stated by teachers in the interviews.

The results show that the opinion about the importance of supporting a feeling of respect and sensitivity toward organisms correlates with the statements that students should have a direct experience with nature $(r=0.77)$.

The same statement about the importance of supporting a feeling of respect and sensitivity toward organisms correlates with the claim that parents' support is needed to shape children's attitudes $(r=0.77)$.

There is also a strong $(r=0.72)$ correlation between opinions about the importance of direct experience with nature and the belief that students are able to teach and influence their parents. The same belief correlates with the opinion about the importance of constructing knowledge in the classroom $(r=0.77)$. This is also presented afterwards in the opinion that the importance of constructing knowledge has correlations with the development of skills $(r=0.63)$ and shaping children's attitudes $(r=0.63)$.

Moreover, the belief about the importance of constructing knowledge in the classroom correlates with the opinions on the importance of changing negative cultural perceptions of amphibians and reptiles $(\mathrm{r}=0.69)$.

Furthermore, opinions on the importance of supporting a feeling of respect and sensitivity toward organisms correlates with an importance of teacher having a sense of the mission (teacher with mission) $(r=0.63)$, which also correlates with the beliefs about the importance of presenting morphology as a result of adaptation to the environment in which amphibians and reptiles live $(r=0.69)$.

The same statement about the importance of a teacher having sense of the mission (teacher with mission) correlates with the opinions about the importance of changing negative cultural perceptions of amphibians and reptiles $(r=0.63)$. Those opinions correlate with the importance of shaping attitudes $(r=0.63)$, which in teachers' opinion also correlates with the concerns about the persistence of misconceptions $(r=0.63)$.

\section{DISCUSSION}

The essential finding arising from the presented research is that students' sources of scientific information cannot be considered to be highly scientific nor a good source of information. None of the analyzed textbooks is ideal-some of them lack proper graphics and some have substantial errors, which can lead to alternative conceptions. Such errors can create a learning opportunity - but only in the case when teachers/readers will notice and correct those. This task is usually addressed to teachers (Driver, Asoko, Leach, Scott, \& Mortimer, 1994), but the authors would like to highlight that especially with a logical error, they can be corrected by students, which would make such an activity fruitful for the majority of class, since it creates the possibility for discussion.

How does the textbook functions as a source of scientific knowledge?

In order to address the first research question in more detail the authors, have discussed obtained results in the context of the findings of other researchers. Textbooks as a source of scientific knowledge are not ideal nor free from errors.

None of the analyzed textbooks presented a hierarchy of the ideas-for example, none of the textbooks undertook evolution in the context of adaptation of amphibians and reptiles toward the environment. The analyzed textbooks seem to have been written for the teacher who knows how to use and manage the information presented in it and not for the students. In that situation, textbooks did not support communication in the classroom. This statement is also supported by the finding that none of the textbooks contained elements or tasks which were cognitively challenging and inspiring for the students to discuss with each other. The majority of the questions presented in the textbooks were related to pure facts, and information presented in the text above that can be 
assigned to low-level tasks (connected to recalling information). They were imitative (or reconstructive) in their nature, and evidently weren't cognitively interesting nor creative. This is surprising, since in science education, a growing interest and research has been observable for a long time regarding the role of open-ended tasks, which can be classified to higher-level tasks (for example, forming and critiquing explanation) (Taber, 2014). Additionally, most of the mistakes or misleading information that appeared in examined textbooks showed how difficult it is to write a good textbook.

As was observed, in light of the content analysis and works of other researchers, authors of textbooks seem not to be aware of the self-teaching role of the textbook or the transformational role that textbooks should undertake (Mayer, Bove, Bryman, Mars, \& Tapangco, 1996). Good textbooks should inspire students and develop their ability to think critically, and simultaneously establish an everyday use of scientific methods (Nosich, 2012). In that case, textbooks can be used by teachers as a tool of communication in the classroom - to discuss different views on students' ideas, with the use of different sources to have a wider spectrum of communication.

That said, those textbooks which possess errors and understatements might be used by a teacher anyway, to exercise critical thinking skills through the analysis of information and evaluation of received information. Critical thinking is a universal ability which, once learned, can be used regardless of the topic (Cottrell, 2011). Critical thinking and questioning of even sources of scientific information is a part of the scientific method (Halpern, 1998) - an application of which should taught regardless of the age or level of education (Kuhn, 1999).

Communication can be occur not only in verbal but also in visual mode. For that reason the authors carried out the analysis of photographs present in textbooks. As was found in this research, there are not many representations of native species of amphibians and reptiles in the textbooks. Native species should be presented in the photographs, so students could be able to recognize them in nature (Celis-Diez et al., 2016). Instead, the majority of analyzed textbooks presented more attractive and colorful species or even, in some cases, species which are invasive in Poland. For example, instead of presenting a native European pond turtle (Emys orbicularis) they presented the red-eared slider (Trachemys scripta elegans) (Codes, 2001), which is an invasive species and is displacing a native one. What is also interesting, in our investigation, is that three out of ten teachers mentioned exotic examples of amphibians and reptiles as the most didactical ones. This is surprising, especially in light of construal level theory, according to which, people tend to create models about unknown elements based on emotions and assumptions, and such models are abstract, in contrast to close objects that result in the formation of concrete models (Trope \& Liberman, 2010). If students do not know native amphibians and reptiles, they will not have experiences with them and will not create positive models about them. This can in consequence lead to mental constructions in which those animals stay in abstract, not concrete models, and thus are still perceived as threatening and disgusting (Prokop \& Tunnicliffe, 2008; Trope \& Liberman, 2010).

What is worth mentioning is that none of the textbooks revealed the slow worm as a lizard, even though it is often mistaken as a snake, as it has no legs. The other graphic representation which may lead to a misconception is presenting the male sand lizard in mating colors in the majority of the photographs. In that way, students may assume that this species looks always like that.

Some textbooks can be considered to be more graphically attractive than others, as they have a transparent compilation and comparison of amphibians and reptiles and show representatives of both clusters. However, only one textbook contained a direct comparison of amphibians and reptiles. This is surprising, since one of the common misconceptions in commonsense herpetology is classifying salamanders and newts (amphibians) as lizards (reptiles) (Crump \& Fenolio, 2015). Thus, such visual comparison should be observed more frequently, because the appropriate schemes or tables are a part of the textbook as important as text content (Mayer et al., 1996). It would be fruitful if authors of textbooks were familiar with research describing common misconceptions and used them as starting points in discussion, description, stories, etc. (Smith, Holliday, \& Austin, 2010). Another important element is the description of presented photographs and the quality of the photographs themselves. For example, it is not only important that the colors of the presented specimens are attractive, but they should also correspond to the reality. Additionally, graphics in textbooks should fulfill self-teaching (and other) roles (Cottrell, 2011; Halpern, 1998; Kuhn, 1999; Nosich, 2012; Roth et al., 1999).

What is worth highlighting here is that the graphical parts of information presented in textbooks were only pictures of the animals. None of the analyzed textbooks contained any graphical representation or annotated illustrations of the idea that could be understood by students. There were not any graphs showing an example of a cause-effect relationship, or interrelationships between different taxa or even a table with a comparison of both groups of analyzed animals. Only one analyzed textbook presented a comparison between two species of snakes. The roles of such graphical aid as annotated illustrations were examined by Meyer and coworkers (1996). These authors have shown that annotated illustrations help students to focus on key explanative information (mainly due to the fact that the explanations are presented without additional, distracting verbal information). Such illustrations also aid learning because they help the learner to construct connections between verbal and visual representations of the explanation, and this helps in problem-solving. They also proved that summaries (a shorter text) are more 
effective in the learning process than a long text-simply by minimalizing the cognitive load. The effect was proven to be better with a combination of visual and verbal summaries. In light of the results presented by them, the amount of information presented in Polish textbooks seems to be too big, and pictures presented there play the role of a colorful ornament, not didactical aids.

What is our major concern is that it is hard to clearly indicate who the recipient of the textbook is. It should be clear that it is students and teachers. But if we take a closer look to the content presented there, we might find ourselves in doubt. Textbooks are filled in with many words, and some pictures, but these words are often misleading, and together with pictures do not refer to everyday knowledge of a child-who should be a major subject here. They lack a core idea that could guide children in the learning process. Such a core idea could serve as a good scaffolding tool, as a hypothesis discussed while the content is presented. Instead, textbooks just report, provide information in a way that is usually boring for children (Bybee, 1989). Such a situation is perceived as a demotivating factor (Al-Khairy, 2013). In the analyzed textbooks, there were no cognitively interesting tasks, which could involve students in the process of finding more information about amphibians or reptiles. Such textbooks fail as a good source of scientific knowledge - they do not involve a child in the process of learning, nor serve as a manner and tool of communication.

The authors wanted to supplement this discussion with the role of the publishing house in the didactic process, in which authors did not succeed. Collecting feedback on textbooks is important for both students and teachers. Especially those textbooks may involve the student more actively, among others, by introducing a core idea or changing the narrative to writing a textbook in the convention of a popular-science book. Another would be to present graphical aids instead of just pictures.

Additionally substantial errors in textbooks are a vast problem and, if they are not corrected by the teacher, might lead to many problems, such as: Failure in external exams, not understanding/having a skewed view of the surrounding world and poor decisions regarding the management of both nature and resources or, in extreme cases, the errors might even be life-threatening (Bizzo \& Caravita, 2012) or at least have consequences in national exams (Sajkowska \& Rybska, 2014). For example, recently, in 2013, during the external exam at the end of the high school, examiners observed many instances in which a piece of incorrect information from one textbook (about the role of pores in the skin of the amphibians in conducting respiration) appeared in the answers of many students (Sajkowska \& Rybska, 2014). Textbooks without a teacher, as a source of scientific knowledge, might not only be insufficient but also misleading. It might be presumed that the publisher does not conduct a thorough enough peerreview process, which might be improved by inviting teachers who has practical experience to this process. If a teacher treats a textbook as a didactical aid, not as a major scientific source of knowledge, they can detect and correct mistakes in textbooks (Ferris, 1995).

What is role of the teacher as a source of scientific knowledge?

As it is presented in the results, the role of a teacher as a source of scientific knowledge is complex and full with nuances. Their teaching styles and reflectiveness toward themselves is diverse, as it is presented below.

During the interviews, the majority of teachers appeared to follow the teaching style defined as either PT or DT in this paper and our study, stressing scientific knowledge while teaching. This result is consistent with opinions from interviews, where teachers claimed that knowledge is the most important element. It can be assumed that in that opinion of teachers, after constructing students' knowledge in the classroom, students might be able to teach their parents. It is striking that those two beliefs correlate more often than statements about the importance of knowledge and developing skills. However, it fits well with our assumptions about the teaching priorities of a didactical teacher and the fact that the majority of the interviewed teachers, regardless of education level, were assigned to this category. Surprisingly, there was not any junior high school teachers assigned to the teaching style defined by us as ethical teachers among the participants chosen for the study. This fits with previous observations by Lickona (2009), who mentioned that it is not very popular in Europe or other parts of the world to conduct ethical lessons during regular classes.

Furthermore, the interviewed teachers, in their statements, often showed a tendency to neglect ethics or the role of shaping attitudes during school activities. This could be assessed by the presence of such statements as: "I don't have time for this (ethics, talking about values) during the lesson", or "shaping attitudes should be done by parents..." or "students can shape them by talking to each other". Teachers emphasized the significance of constructing students' knowledge as their most important role in the classroom. The development of skills or shaping attitudes was less crucial in their opinion. However, at the same time, the teachers are aware of the presence of both negative attitudes toward amphibians and reptiles and negative cultural perception of those groups causing misconceptions. The importance of the connection between attitudes and cultural perception can be seen in the work of Ceríaco (2012), where the author presents that many amphibians and reptiles have a negative cultural image, which might lead to misconceptions and unnecessary killing of those animals. Some of those misconceptions are strongly connected with folk biology (Crump \& Fenolio, 2015), and changing them might be impossible, as they are the part of heritage. Amphibians and reptiles are killed as a consequence of those beliefs (Crump \& Fenolio, 
2015). Therefore, it is crucial for teachers to be aware of this cause and effect link in order to put more stress on shaping the attitudes during didactic process. But to be aware of this, teachers have to be reflective.

The ideal teacher should use all three teaching styles in harmony - be DT, ET, and PT and be reflective. It should be stressed that being reflective is one of the most important skills and activity every teacher should possess. In such cases, the ideal teacher would be presented as a reflective DEPT, which is not a separate style, but a metacategory above teaching styles integrating all desirable factors. The meaning of reflective DEPT is that a teacher's personality and attitude is crucial, since he or she is shaping students' minds (provides information, serves as a template, shows pathways, shapes attitudes, puts value into their own statement-influencing through all of that students' minds). The authors expect from the teacher to be all inclusive - at the same time teaching and raising the student as a mature and responsible citizen. This seems to be possible with a teacher who possesses a reflective DEPT teaching style. There is a lot of research about ethical Teachers, but unfortunately, they mainly consider the teacher as a person who should act ethically and not transfer their own beliefs to students (Campbell, 2003), and this is not the approach which authors undertook in this study. Shaping attitudes is strongly connected with the values that a person holds. It seems to be extremely difficult to create a universal pattern of values every teacher in every country in the world should present, since different values are important in different countries. On the other hand, we all might agree on a few core ones that should be common when talking about science education. The values such as responsibility for our actions, environmental protection, etc. would be present among them.

Furthermore, a dedicated teacher with the sense of the mission might change those misconceptions by changing negative attitudes, even though that might be the hardest task for the teacher in the classroom. In addition, this challenge is more often faced by teachers in primary schools than in junior high schools. However, Watt and Richardson (2008) claim that this might not be connected with the school level but with the role of the teacher, which has been changed over the years. On the other hand, it is well known that experience with an object leads to respect. Chawla and Cushing (2007) presented that even the best longitude environmental education program will not replace good environmental education at home. Thus, school education should at least support it or cooperate rather than neglect presenting issues connected with shaping attitudes. As Vaughan and coworkers (Vaughan, Gack, Solorazano, \& Ray, 2003) showed, all of these elements should be connected (motivated students, teacher, and parent) if they are to lead to successes in the form of environmentally aware and reflective citizens.

\section{CONCLUSIONS}

Students' sources of scientific information are the most commonly used tools in the education process, as they play a role in the process of constructing knowledge, developing skills, and shaping attitudes. However, at the same time, they can also be sources of misconceptions and/or missed teaching opportunities. What is more, they can cause some of the problems-usually communication between all people involved in designing and using scientific textbooks does not exist. Additionally, we might observe that teachers tend to use very limited sources of students' scientific information in addition to themselves and textbooks.

Therefore, in the example of topics of amphibians and reptiles, we presented the results of content analysis of Polish biology textbooks, and in-depth interviews of biology teachers for educational levels from primary school to junior high school.

None of the analyzed textbooks was free from errors. Additionally, none of them fulfilled the motivational function or contained an apparent "bigger idea" which might influence a student's appreciation or understanding of these animals (by providing a bigger picture). We also proposed a model of categorization of dominant teaching styles through the distinction of three major categories: Didactical, ethical, and pedagogical teacher/teaching style. In our research, there was only one teacher that could have been categorized as an ethical teacher with the potential to be a reflective DEPT. The majority of teachers presented the didactical style as the dominant one. We also found out that for the majority of teachers, the most important part of their job is to help their students to construct knowledge and skills but not to shape attitudes. Such declarations are common among teachers, despite the fact that shaping attitudes has been shown to play a crucial role in any education system. Our results also showed that there is a strong correlation between a teacher's claims that respect toward organisms is significant and claims about the importance of a direct experience with nature. Remarkably, even though the interviewed teachers were aware of this necessity, at the same time, they did not stress the value of shaping attitudes during lessons. Part of the problem lies in the small number of hours of biology devoted to its teaching (in junior-high school it is 1 hour per week). Teachers give this as the main reason for not doing fieldwork with students.

\section{Implications}

One possible resolution of this problem would be to conduct classes which will give students the opportunity to have a direct experience, which will shape attitudes and motivate respect for living organisms, with the use of good textbooks as an additional supplementary teaching tool. With unlimited access to information, teachers 
should be able to create influential and complex classes, which would shape students' attitudes. Teachers with an ethical style of teaching will be able to conduct it, and as presented in this article, the majority of the analyzed teachers possess the necessary elements to create and promote this teaching style, as it is the most suitable in the modern classroom.

\section{REFERENCES}

Abimbola, I. O., \& Baba, S. (1996). Misconceptions \& alternative conceptions in science textbooks: The role of teachers as filters. The American Biology Teacher, 14-19. https:/ / doi.org/10.2307/4450067

Al-Khairy, M. H. (2013). English as a foreign language learning demotivational factors as perceived by Saudi undergraduates. European Scientific Journal, ESJ, 9(32).

Babbie, E., \& Benaquisto, L. (2009). Fundamentals of Social Research (2 edition). Canada: Nelson College Indigenous.

Barrass, R. (2010). Some misconceptions and misunderstandings perpetuated by teachers and textbooks of biology. Journal of Biological Education, 18, 201-206. https:/ / doi.org/10.1080/00219266.1984.9654636

Barron, B., \& Darling-Hammond, L. (2008). Teaching for Meaningful Learning: A Review of Research on Inquiry-Based and Cooperative Learning. Book Excerpt. George Lucas Educational Foundation. Retrieved from https:/ / eric.ed.gov/?id=ED539399

Barrow, L. H. (2002). What do elementary students know about insects? Journal of Elementary Science Education, 5360. https:/ / doi.org/10.1007/BF03173848

Basińska, A., Pietrala, D., Cole, R., \& Dziubalska-Kołaczyk, K. (2012). ETOS-innowacyjne narzędzie wspomagające nauczanie i uczenie się przedmiotów przyrodniczych.

Bizzo, N., \& Caravita, S. (2012). School textbooks and updated sound science: narrowing the gap between classrooms and cutting edge science. https:/ / doi.org/10.1080/00219266.2012.659112

Böhm, M., Collen, B., Baillie, J. E., Bowles, P., Chanson, J., Cox, N., ... Rhodin, A. G. (2013). The conservation status of the world's reptiles. Biological Conservation, 157, 372-385. https:// doi.org/10.1016/j.biocon.2012.07.015

Braund, M. (1991). Children's ideas in classifying animals. Journal of Biological Education, 25(2), 103-110. https:/ / doi.org/10.1080/00219266.1991.9655186

Brookfield, S. D. (1995). Becoming a Critically Reflective Teacher (1st edition). San Francisco: Jossey-Bass.

Brown, B. L. (2003). Teaching Style vs. Learning Style. Myths and Realities.

Brzezińska, A. I. (2008). Nauczyciel jako organizator społecznego środowiska uczenia się. [Teacher as organizer of social teaching environment.] W: E. Filipiak (red.), Rozwijanie zdolności uczenia się. Wybrane konteksty i problemy (s. 35-50). Bydgoszcz: Wyd. Uniwersytetu Kazimierza Wielkiego UKW

Bybee, R. W. (1989). Teaching high school biology: Materials and strategies. High school biology today and tomorrow, 165-177.

Calado, F. M., Scharfenberg, F.-J., \& Bogner, F. X. (2015). To What Extent do Biology Textbooks Contribute to Scientific Literacy? Criteria for Analysing Science-Technology-Society-Environment Issues. Education Sciences, 5(4), 255-280. https:/ / doi.org/10.3390/educsci5040255

Campbell, E. (2003). The ethical teacher. McGraw-Hill Education (UK).

Cardak, O. (2009). Science students misconceptions about birds. Scientific Research and Essays, 4(12), 1518-1522.

Celis-Diez, J. L., Díaz-Forestier, J., Márquez-García, M., Lazzarino, S., Rozzi, R., \& Armesto, J. J. (2016). Biodiversity knowledge loss in children's books and textbooks. Frontiers in Ecology and the Environment, 14(8), 408-410. https:/ / doi.org/10.1002/fee.1324

Ceríaco, L. M. (2012). Human attitudes towards herpetofauna: The influence of folklore and negative values on the conservation of amphibians and reptiles in Portugal. Journal of Ethnobiology and Ethnomedicine, 8(1), 8. https:/ / doi.org/10.1186/1746-4269-8-8

Chawla, L., \& Cushing, D. F. (2007). Education for strategic environmental behavior. Environmental Education Research, 13(4), 437-452. https:/ / doi.org/10.1080/13504620701581539

Codes, C. (2001). The red-eared terrapin Trachemys scripta elegans (Wied, 1839) in the Lubuskie province (western Poland). Przeglad Zoologiczny, 45(1-2), 103-109.

Costa, M. J., Howitt, S., Anderson, T., Hamilton, S., \& Wright, T. (2008). A concept inventory for molecular life sciences: how will it help your teaching practice?

Cottrell, S. (2011). Critical thinking skills. Palgrave Macmillan Basingstoke. https://doi.org/10.1007/978-0-23034489-1 
Creswell, J. W., \& Miller, D. L. (2000). Determining validity in qualitative inquiry. Theory into Practice, 39(3), 124130. https://doi.org/10.1207/s15430421tip3903_2

Crump, M., \& Fenolio, D. B. (2015). Eye of Newt and Toe of Frog, Adder's Fork and Lizard's Leg: The Lore and Mythology of Amphibians and Reptiles. University of Chicago Press. https:/ / doi.org/10.7208/chicago/9780226116143.001.0001

de Irala, J., Urdiain, I. G., \& López Del Burgo, C. (2008). Analysis of content about sexuality and human reproduction in school textbooks in Spain. Public Health, 122(10), 1093-1103. https:/ / doi.org/10.1016/j.puhe.2008.01.005

Driver, R., Asoko, H., Leach, J., Scott, P., \& Mortimer, E. (1994). Constructing scientific knowledge in the classroom. Educational Researcher, 23(7), 5-12. https:/ / doi.org/10.3102/0013189X023007005

Dufresne, R. J., Gerace, W. J., Leonard, W. J., Mestre, J. P., \& Wenk, L. (1996). Classtalk: A classroom communication system for active learning. Journal of Computing in Higher Education, 7(2), 3-47. https:/ / doi.org/10.1007/BF02948592

Edling, A. (2006). Abstraction and authority in textbooks The textual paths towards specialized language. Uppsala: Universitetsbiblioteket. $\quad$ Retrieved from http://uu.divaportal.org/smash/get/diva2:168583/FULLTEXT01.pdf

Erdoğan, M., Coşkun, E., \& Uşak, M. (2011). Developing children's environmental literacy through literature: An analysis of 100 basic literary works. Eğitim Araştırmaları-Eurasian Journal of Educational Research, 42, 45-62.

Fay, N., Garrod, S., Lee, J., \& Oberlander, J. (2003). Understanding interactive graphical communication (Vol. 25). Presented at the Proceedings of the Annual Meeting of the Cognitive Science Society.

Felder, R. M., \& Brent, R. (2005). Understanding student differences. Journal of Engineering Education, 94(1), 57-72. https:/ / doi.org/10.1002/j.2168-9830.2005.tb00829.x

Ferris, D. R. (1995). Student reactions to teacher response in multiple-draft composition classrooms. TESOL Quarterly, 29(1), 33-53. https:/ / doi.org/10.2307/3587804

Friedrichsen, P. J., Abell, S. K., Pareja, E. M., Brown, P. L., Lankford, D. M., \& Volkmann, M. J. (2009). Does teaching experience matter? Examining biology teachers' prior knowledge for teaching in an alternative certification program. Journal of Research in Science Teaching: The Official Journal of the National Association for Research in Science Teaching, 46(4), 357-383. https:// doi.org/10.1002/ tea.20283

Gardner, T. A., Barlow, J., \& Peres, C. A. (2007). Paradox, presumption and pitfalls in conservation biology: the importance of habitat change for amphibians and reptiles. Biological conservation, 138(1-2), 166-179. https://doi.org/10.1016/j.biocon.2007.04.017

Gatt, S., Tunnicliffe, S. D., Borg, K., \& Lautier, K. (2007). Young Maltese children's ideas about plants. Journal of Biological Education, 41(3), 117-122. https:/ / doi.org/10.1080/00219266.2007.9656080

Gericke, N. (2009). Science versus School-science : Multiple models in genetics - The depiction of gene function in upper secondary textbooks and its influence on students' understanding. DIVA. Retrieved from http:/ / urn.kb.se/resolve?urn=urn:nbn:se:kau:diva-3177

Ghaderi, M. (2010). The comparison analysis of the science textbooks and teacher's guide in Iran with America (science anytime). Procedia-Social and Behavioral Sciences, 2(2), 5427-5440. https://doi.org/10.1016/j.sbspro.2010.03.886

Gibbons, J. W., Scott, D. E., Ryan, T. J., Buhlmann, K. A., Tuberville, T. D., Metts, B. S., ... \& Winne, C. T. (2000). The Global Decline of Reptiles, Déjà Vu Amphibians: Reptile species are declining on a global scale. Six significant threats to reptile populations are habitat loss and degradation, introduced invasive species, environmental pollution, disease, unsustainable use, and global climate change. BioScience, 50(8), 653-666. https:/ / doi.org/10.1641/0006-3568(2000)050[0653:TGDORD]2.0.CO;2

Grow, G. O. (1991). Teaching learners to be self-directed. Adult Education Quarterly, 41(3), 125-149. https:/ / doi.org/10.1177/0001848191041003001

Halpern, D. F. (1998). Teaching critical thinking for transfer across domains. Dispositions, skills, structure training, and metacognitive monitoring. The American Psychologist, 53(4), 449-455. https://doi.org/10.1037/0003066X.53.4.449

Izquierdo, M., Marquez, C., \& Gouvea, G. (2008). A Proposal for Textbooks Analysis: Rhetorical Structures. Science Education International, 19(2), 209-218.

Jakobson, R. (1987). Linguistics and poetics. Language in Literature, 527, 62-94.

Jefferies, P., Carsten-Stahl, B., \& McRobb, S. (2007). Exploring the relationships between pedagogy, ethics and technology: Building a framework for strategy development. Technology, Pedagogy and Education, 16(1), 111126. https:/ / doi.org/10.1080/14759390601168122 
Kandzia, J. (2018). Kształtowanie wartości dydaktycznych $i$ wychowawczych w procesie edukacji matematycznej $z$ wykorzystaniem technik multimedialnych. [Forming didactic and educational values in the process of mathematical education with the use of multimedia techniques.] Oficyna Wydawnicza Impuls.

Kubiatko, M., Usak, M., \& Pecusova, E. (2011). Elementary school pupils' knowledge and misconceptions about birds. Eurasian Journal of Educational Research, 43, 163-181.

Kuhn, D. (1999). A Developmental Model of Critical Thinking A Developmental Model of Critical Thinking. Educational Researcher, 28(2), 16-46. https:// doi.org/10.3102/0013189X028002016

Lau, K. H., Lam, T., Kam, B. H., Nkhoma, M., Richardson, J., \& Thomas, S. (2018). The role of textbook learning resources in e-learning: A taxonomic study. Computers $\mathcal{E}$ Education, 118, 10-24. https:/ / doi.org/10.1016/j.compedu.2017.11.005

Lee, V. R. (2010). Adaptations and continuities in the use and design of visual representations in US middle school science textbooks. International Journal of Science Education, 32(8), 1099-1126. https:/ / doi.org/10.1080/09500690903253916

Lemke, J. L. (1988). Text structure and text semantics. Pragmatics, Discourse, and Text. London: Pinter, 158-170.

Lickona, T. (2009). Educating for character: How our schools can teach respect and responsibility. Bantam.

Lips, K. R., Burrowes, P. A., Mendelson III, J. R., \& Parra-Olea, G. (2005). Amphibian Declines in Latin America: Widespread Population Declines, Extinctions, and Impacts 1. Biotropica: The Journal of Biology and Conservation, 37(2), 163-165. https:/ / doi.org/10.1111/j.1744-7429.2005.00023.x

Lumpe, A. T., \& Scharmann, L. C. (1991). Meeting contemporary goals for lab instruction: A content analysis of two secondary biology textbooks. School Science and Mathematics, 91(6), 231-235. https:/ / doi.org/10.1111/j.19498594.1991.tb12088.x

Mackay, L. D. (1971). Development of understanding about the nature of science. Journal of Research in Science Teaching, 8(1), 57-66. https:/ / doi.org/10.1002/tea.3660080110

Magnusson, S., Krajcik, J., \& Borko, H. (1999). Nature, sources, and development of pedagogical content knowledge for science teaching. In Examining pedagogical content knowledge (pp. 95-132). Springer. https:/ / doi.org/10.1007/0-306-47217-1_4

Mayer, R. E., Bove, W., Bryman, A., Mars, R., \& Tapangco, L. (1996). When less is more: Meaningful learning from visual and verbal summaries of science textbook lessons. Journal of Educational Psychology, 88(1), 64. https://doi.org/10.1037/0022-0663.88.1.64

Miller, P. (2001). Learning Styles: The Multimedia of the Mind. Research Report.

National Research Council. (2012). A framework for K-12 science education: Practices, crosscutting concepts, and core ideas. National Academies Press.

Nosich, G. M. (2012). Learning to think things through: A guide to critical thinking across the curriculum.

Okoń, W. (2003). Wprowadzenie do dydaktyki ogólnej. [Introduction to general didactics.] . Warszawa: Wydawnictwo Akademickie' '̇ak'.

Pea, R. D. (1994). Seeing what we build together: Distributed multimedia learning environments for transformative communications. The Journal of the Learning Sciences, 3(3), 285-299. https://doi.org/10.1207/s15327809jls0303_4

Postigo, Y., \& López-Manjón, A. (2018). Images in biology: are instructional criteria used in textbook image design? International Journal of Science Education, 1-20.

Prokop, P., \& Tunnicliffe, S. D. (2008). “Disgusting” Animals: Primary School Children's Attitudes and Myths of Bats and Spiders. Eurasia Journal of Mathematics, Science and Technology Education, 4(2), 87-97. https:/ / doi.org/10.12973/ ejmste/75309

Roth, W., Bowen, G. M., \& McGinn, M. K. (1999). Differences in graph-related practices between high school biology textbooks and scientific ecology journals. Journal of Research in Science Teaching: The Official Journal of the National Association for Research in Science Teaching, 36(9), 977-1019. https://doi.org/10.1002/(SICI)10982736(199911)36:9<977::AID-TEA3>3.0.CO;2-V

Rubenstein, R. N. (2000). Word origins: Building communication connections. Mathematics Teaching in the Middle School, 5(8), 493.

Russell, B. A. W. (1912). The Problems of Philosophy. London. Oxford U.P., London: William and Norgate.

Sajkowska, Z. A., \& Rybska, E. (2014). Does amphibians and reptiles are the same family? Herpetology in Polish textbooks. Edukacja Biologiczna i Środowiskowa, (s1), 92-98. 
Saunders, K. J., \& Rennie, L. J. (2013). A pedagogical model for ethical inquiry into socioscientific issues in science. Research in Science Education, 43(1), 253-274. https:/ / doi.org/10.1007/s11165-011-9248-Z

Schulman, M., \& Mekler, E. (1986). Bringing up a Moral Child. Behaviorism, 14(1), 65-68.

Seel, N. M. (2011). Encyclopedia of the Sciences of Learning. Springer Science \& Business Media.

Silverman, D. (2013). Doing qualitative research: A practical handbook. SAGE Publications Limited.

Slavin, R. E. (2008). Cooperative Learning, Success for All, and Evidence-based Reform in education. Éducation et Didactique, 2(vol 2-n²), 149-157. https:/ / doi.org/10.4000/educationdidactique.334

Smith, B. L., Holliday, W. G., \& Austin, H. W. (2010). Students' comprehension of science textbooks using a question-based reading strategy. Journal of Research in Science Teaching: The Official Journal of the National Association for Research in Science Teaching, 47(4), 363-379. https:/ / doi.org/10.1002/ tea.20378

Stitt-Gohdes, W. L. (2001). Business Education Students' Preferred Learning Styles and Their Teachers' Preferred Instructional Styles: Do They Match?. Delta Pi Epsilon Journal, 43(3), 137-151.

Szyling, G. (2011). Nauczycielskie praktyki oceniania poza standardami. [Teacher practice of assessment outside of standards.] Oficyna Wydawnicza Impuls.

Taber, K. S. (2014). Constructing active learning in chemistry: Concepts, cognition and conceptions. In Learning with understanding in the chemistry classroom (pp. 5-23). Springer. https:// doi.org/10.1007/978-94-007-4366-3_1

Tomažič, I., \& Šorgo, A. (2017). Factors Affecting Students' Attitudes Toward Toads. Eurasia Journal of Mathematics, Science and Technology Education, 13(6), 2505-2528. https:/ / doi.org/10.12973/ eurasia.2017.01237a

Trigwell, K., Prosser, M., \& Waterhouse, F. (1999). Relations between teachers' approaches to teaching and students' approaches to learning. Higher Education, 37(1), 57-70. https:/ / doi.org/10.1023/ A:1003548313194

Trope, Y., \& Liberman, N. (2010). Construal-level theory of psychological distance. Psychological Review, $117(2), 440$. https://doi.org/10.1037/a0018963

Trowbridge, J. E., \& Mintzes, J. J. (1988). Alternative conceptions in animal classification: A cross-age study. Journal of Research in Science Teaching, 25(7), 547-571. https:/ / doi.org/10.1002/tea.3660250704

van Dijk, E. M., \& Kattmann, U. (2007). A research model for the study of science teachers' PCK and improving teacher education. Teaching and Teacher Education, 23(6), 885-897. https:/ / doi.org/10.1016/j.tate.2006.05.002

Vaughan, C., Gack, J., Solorazano, H., \& Ray, R. (2003). The effect of environmental education on schoolchildren, their parents, and community members: A study of intergenerational and intercommunity learning. The Journal of Environmental Education, 34(3), 12-21. https:/ / doi.org/10.1080/00958960309603489

Vera E. R., (2018) Textbooks and Education. In: Fuchs E., Bock A. (eds) The Palgrave Handbook of Textbook Studies. Palgrave Macmillan, New York.

Vitt, L. J., \& Caldwell, J. P. (2013). Herpetology: an introductory biology of amphibians and reptiles. Academic press. https:/ / doi.org/10.1016/B978-0-12-386919-7.00002-2

Watt, H. M., \& Richardson, P. W. (2008). Motivations, perceptions, and aspirations concerning teaching as a career for different types of beginning teachers. Learning and Instruction, 18(5), 408-428. https:/ / doi.org/10.1016/j.learninstruc.2008.06.002

Wendland, M. (2011). Konstruktywizm komunikacyjny (Vol. 1). Wydawnictwo Naukowe Instytutu Filozofii UAM.

Yates, T. B., \& Marek, E. A. (2014). Teachers teaching misconceptions: a study of factors contributing to high school biology students' acquisition of biological evolution-related misconceptions. Evolution: Education and Outreach, 7(1), 7. https:/ / doi.org/10.1186/s12052-014-0007-2

Yen, C.-F., Yao, T.-W., \& Chiu, Y.-C. (2004). Alternative conceptions in animal classification focusing on amphibians and reptiles: A cross-age study. International Journal of Science and Mathematics Education, 2(2), 159-174. https:/ / doi.org/10.1007/s10763-004-1951-z

Yip, D. (1998). Identification of misconceptions in novice biology teachers and remedial strategies for improving biology learning. International Journal of Science Education, 20(4), 461-477. https:/ / doi.org/10.1080/0950069980200406

Zembylas, M. (2007). Emotional ecology: The intersection of emotional knowledge and pedagogical content knowledge in teaching. Teaching and Teacher Education, 23(4), 355-367. https:/ / doi.org/10.1016/j.tate.2006.12.002 


\section{APPENDIX}

\section{Questions from the Interview, Categories and Examples of the Answers of the Teachers}

Researchers divided all interview questions on two parts - 1: General characteristic of the teacher (questions 1$3 ; 5 ; 10$ ) and 2: Herpetological knowledge of the teacher (questions 4;6-9). Factors with frequency lower than three were pooled out of the analysis.

\begin{tabular}{|c|c|c|c|}
\hline No & $\begin{array}{l}\text { Question from interview/ } \\
\text { Themes }\end{array}$ & Example of the answer & Code \\
\hline 1. & $\begin{array}{l}\text { What is most important in } \\
\text { teaching? Knowledge, skills, or } \\
\text { Attitudes? }\end{array}$ & $\begin{array}{l}\text { "In my classroom the most important is } \\
\text { knowledge, because students can use it in the } \\
\text { future on the exams" } \\
\text { "The most important is knowledge and skills } \\
\text { which might arise from it. If students use what } \\
\text { they learn or they will put in practice, they will } \\
\text { remember learned information longer." }\end{array}$ & $\begin{array}{l}\text { Knowledge } \\
\text { Skills } \\
\text { Attitudes, }\end{array}$ \\
\hline 2. & $\begin{array}{l}\text { What role plays biology in the } \\
\text { process of education of the } \\
\text { students? Is it there some special } \\
\text { dimension, and if so, why? }\end{array}$ & $\begin{array}{l}\text { "I think all of the subjects in school, are important } \\
\text { and they fulfill each other. If I had to choose why } \\
\text { biology is special, or have some special } \\
\text { opportunities it would be creating sensitivity and } \\
\text { respect towards living organism." }\end{array}$ & respect \\
\hline 3. & $\begin{array}{l}\text { Does the teaching of zoology } \\
\text { have a special role in teaching } \\
\text { biology? }\end{array}$ & $\begin{array}{l}\text { "I don't think that zoology have some special } \\
\text { place in teaching biology...If already it have to } \\
\text { had some meaning, it shows how animal is built, } \\
\text { and how morphology have to be connected with } \\
\text { their adaptation to environment." }\end{array}$ & Morphology \\
\hline \multirow[t]{2}{*}{4.} & $\begin{array}{l}\text { Common mistakes among } \\
\text { students }\end{array}$ & $\begin{array}{l}\text { "The most common error which I observe while } \\
\text { teaching about amphibians and reptiles made by } \\
\text { students is thinking that slow worm is a snake, } \\
\text { because it has no legs." }\end{array}$ & misconceptions \\
\hline & & $\begin{array}{l}\text { "Many students doesn't know amphibians and } \\
\text { reptiles as they never met one and thinks that they } \\
\text { are ugly. I also wouldn't take a frog to hand." }\end{array}$ & culture \\
\hline \multirow[t]{3}{*}{5.} & $\begin{array}{l}\text { Who can influence students' } \\
\text { attitudes - school, the media or } \\
\text { parents? }\end{array}$ & $\begin{array}{l}\text { "I think the most important is to influence } \\
\text { students attitudes are their own experiences of the } \\
\text { nature. It is crucial to recognize animals in the } \\
\text { wild." }\end{array}$ & experiences \\
\hline & & $\begin{array}{l}\text { "I think the most important are parent - from their } \\
\text { influence depends if children in the future will go } \\
\text { outside and explore the nature by themselves." }\end{array}$ & \\
\hline & & $\begin{array}{l}\text { I think that the most important is school, as when } \\
\text { children get the knowledge in school the can teach } \\
\text { their parent and shape their pro-environmental } \\
\text { attitudes." }\end{array}$ & $\begin{array}{l}\text { children teach } \\
\text { parents, }\end{array}$ \\
\hline 6. & $\begin{array}{l}\text { Is teaching an occupation or a } \\
\text { mission for you? }\end{array}$ & $\begin{array}{l}\text { "I think no one would do this without some sense } \\
\text { of the mission." } \\
\text { "In my opinion vocation-mission is necessary, } \\
\text { without it you can't be a good teacher if you refuse } \\
\text { to influence students' lives." }\end{array}$ & $\begin{array}{l}\text { teacher with a } \\
\text { mission }\end{array}$ \\
\hline
\end{tabular}




\section{List of Analyzed Textbooks}

\begin{tabular}{|c|c|c|c|c|}
\hline No Title & Publishing house & Level of education & Class & Year of publication \\
\hline 1 Puls życia 1 & Nowa era & Junior high school & Class & 2009 \\
\hline 2 Biologia $\mathrm{z}$ tangramem 2 & Tangram & Junior high school & 1 & 2010 \\
\hline 3 Ciekawa biologia 2 & WSiP & Junior high school & 2 & 2012 \\
\hline 4 Bliżej biologii & WSiP & Junior high school & 2 & 2011 \\
\hline 5 Z natury rzeczy & MAC & Junior high school & 2 & 2009 \\
\hline 6 Świat biologii 1 & Nowa era & Junior high school & 2 & 2009 \\
\hline 7 Biologia 2 & Operon & Junior high school & 1 & 2010 \\
\hline 8 Biologia dla gimnazjum & $\dot{\mathrm{Z} a k}$ & Junior high school & 2 & 2010 \\
\hline 9 Przyroda 5 & Operon & Primary school & 2 & 2010 \\
\hline $10 \mathrm{Na}$ tropach przyrody 4 & Nowa era & Primary school & 5 & 2012 \\
\hline 11 Przyrodo witaj 6 & WSiP & Primary school & 4 & 2014 \\
\hline 12 Tajemnice przyrody 6 & Nowa era & Primary school & 6 & 2010 \\
\hline
\end{tabular}

\section{http://www.ejmste.com}

